\title{
A temperature index in a Late Quaternary sequence at Wonderkrater, South Africa
}

AUTHOR:

J. Francis Thackeray ${ }^{1}$

\section{AFFILIATION:}

${ }^{1}$ Evolutionary Studies Institute, School of Geosciences, University of the Witwatersrand, Johannesburg, South Africa

\section{CORRESPONDENCE TO: Francis Thackeray}

\section{EMAIL:}

Francis.thackeray@wits.ac.za

\section{KEYWORDS:}

Younger Dryas; age-depth relationships; pollen spectra; radiocarbon dates

\section{HOW TO CITE:}

Thackeray JF. A temperature index in a Late Quaternary sequence at Wonderkrater, South Africa. S Afr J Sci. 2018;114(5/6), Art. \#a0268, 2 pages. http://dx.doi. org/10.17159/sajs.2018/a0268

\section{PUBLISHED:}

30 May 2018
Wonderkrater is a Late Quaternary archaeological site in the Limpopo Province of South Africa', and has a high-resolution Late Quaternary pollen sequence ${ }^{2-4}$. An initial multivariate analysis of pollen spectra facilitated the quantification of a temperature index (SSF1) for two borehole sequences. ${ }^{5}$ An attempt to calibrate the SSF1 temperature indices was made by Thackeray ${ }^{6}$. Scott et al. ${ }^{7}$ and Thackeray and Scott ${ }^{8}$ identified the 'Younger Dryas' cooling event in Borehole 3. This palaeoclimatic phenomenon is generally known in the northern hemisphere, dated between 10600 and $12900 \mathrm{BP}$ (calibrated years). In this study, palaeotemperature estimates from the initial multivariate study ${ }^{5}$ are re-examined in the context of calibrated radiocarbon dates ${ }^{7}$ in order to make comparisons with dates for the Younger Dryas in the northern hemisphere.

\section{Age-depth relationships}

On the basis of the SSF1 palaeotemperature index, Thackeray and Scott ${ }^{8}$ recognised certain Wonderkrater samples as being associated with the Younger Dryas. Critical in this regard are dates for the relevant deposits. Scott et al. ${ }^{3}$ and $\mathrm{Scott}{ }^{4}$ have used various techniques to resolve chronological issues. Whereas there is a linear relationship between age and depth for the last 16000 years BP, the rate of deposition is not constant for earlier deposits for which the rate is slower and variable; hence the need for complex chronological modelling which presented a major challenge. ${ }^{3,4}$ However, for purposes of this study, attention is focused on age-depth relationships for the Terminal Pleistocene and Holocene, within the last 16000 years, for periods in which least squares linear regression is suitable. This offers a relatively simple but robust approach for dating postglacial deposits at Wonderkrater.

Three age-depth relationships were obtained by using calibrated radiocarbon dates (and associated standard deviations) for 12 Late Pleistocene and Holocene samples ${ }^{7}$ from Borehole 3, using linear regression analyses. All 12 of these samples were selected by Scott et al. ${ }^{7}$ because they were considered to be reliable. Others were deliberately excluded because they were outliers and were assumed to be associated with contamination by roots.

Equation 1 is obtained by relating mean values for calibrated radiocarbon dates (CAL-1,y-axis) and depth (D, $x$-axis), for the 12 samples selected by Scott et al. ${ }^{7}$ in their Table 1:

CAL-1 $=40.423 \mathrm{D}-1431.30(\mathrm{r}=0.99)$

Equation 1

Equation 2 is obtained by relating depth to chronological values which are two standard deviations below the mean CAL-1 date for each sample:

CAL-2 $=39.696 \mathrm{D}-1487.98(r=0.99)$ Equation 2

Equation 3 is obtained by relating depth to chronological values which are two standard deviations above the mean CAL-1 date for each sample:

CAL-3 $=41.182 \mathrm{D}-1413.32(\mathrm{r}=0.99)$

Equation 3

On the basis of depth, all three equations were applied in order to estimate dates for 50 samples from Borehole 3 . Estimates for CAL-1 relative to the SSF1 palaeotemperature index are shown in Figure 1.

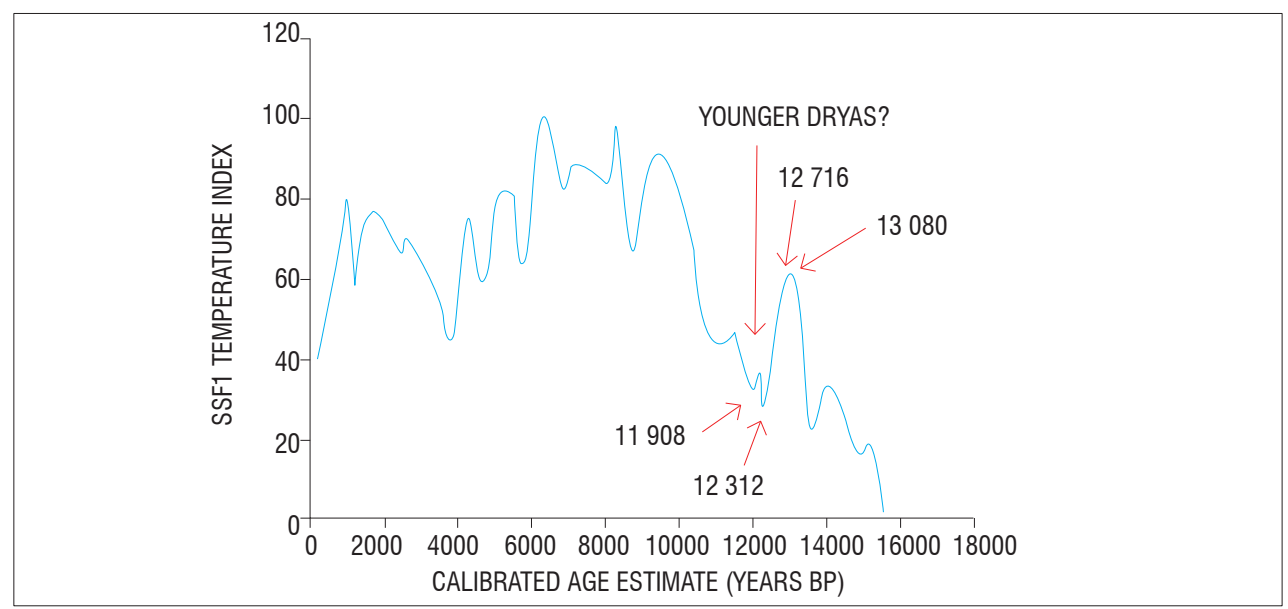

Figure 1: A temperature index (SSF1) based on multivariate analysis of pollen spectra from Wonderkrater in relation to estimated CAL-1 dates (cal years BP) based on Equation 1. A cooling event appears to occur after 12716 cal years BP - here associated with the onset of the Younger Dryas which is well documented in the northern hemisphere where it is dated between 12900 and 11600 cal years BP. 


\section{Dates in relation to temperature index}

Notable in Figure 1 and Table 1 is that relatively low temperatures are identified at 12312 cal years BP (sample 5609), continuing to $12100 \mathrm{cal}$ years BP (sample 5606) and further to 11908 cal years BP (sample 5605). This cool event appears to be initiated at 12716 cal years BP (sample 5611) after a slightly warmer period at 13080 cal years BP (sample 5613).

Table 1: Wonderkrater samples listed by number; depth (cm); calibrated dates (CAL-1, CAL-2 and CAL-3 estimates based on Equations 1-3); and SSF1 temperature indices based on multivariate analyses of pollen spectra from Borehole 3 , Wonderkrater sequence $e^{5}$. CAL-2 and CAL-3 are the lower and upper limits (two standard deviations), respectively, for estimates of the mean calibrated dates (CAL-1).

\begin{tabular}{c|c|c|c|c|c}
\hline \hline Sample \# & Depth & $\begin{array}{c}\text { CAL-2 } \\
\text { (lower limit) }\end{array}$ & $\begin{array}{c}\text { CAL-1 } \\
\text { (mean) }\end{array}$ & $\begin{array}{c}\text { CAL-3 } \\
\text { (upper limit) }\end{array}$ & SSF1 \\
\hline 5599 & 300 & 10420 & 10695 & 10941 & 46 \\
\hline 5601 & 310 & 10817 & 11099 & 11353 & 43 \\
\hline 5603 & 320 & 11214 & 11504 & 11765 & 46 \\
\hline 5605 & 330 & 11611 & 11908 & 12177 & 32 \\
\hline 5606 & 335 & 11810 & 12110 & 12382 & 37 \\
\hline 5609 & 340 & 12008 & 12312 & 12588 & 29 \\
\hline 5611 & 350 & 12405 & 12716 & 13000 & 57 \\
\hline 5613 & 359 & 12762 & 13080 & 13371 & 61 \\
\hline 5615 & 365 & 13001 & 13323 & 13618 & 37 \\
\hline
\end{tabular}

In the context of lower (CAL-2) and upper (CAL-3) limits for estimated CAL-1 dates (Table 1), the results from this study are consistent with calibrated radiocarbon dates for the Younger Dryas in the northern hemisphere. At Wonderkrater, sample 5611 at $12716 \mathrm{cal}$ years BP is close to the date of $12900 \mathrm{cal}$ years BP for the onset of the Younger Dryas in the northern hemisphere. ${ }^{9}$

\section{The Younger Dryas in Borehole 4}

The Younger Dryas is also represented in Borehole 4. On the basis of palaeotemperature indices for this sequence, a cooling episode can be identified from at least one sample. ${ }^{3,4}$ The calibrated date of circa 12200 $\mathrm{BP}$ for this sample from Borehole 4 is almost identical to the mean date (12 $433 \mathrm{cal} \mathrm{BP}$ ) for the three Younger Dryas samples from Borehole 3.

\section{The Younger Dryas and a cosmic impact?}

Among others, Kennett et al. ${ }^{10}$ have claimed that the Younger Dryas cooling event may be associated with a cosmic impact of some kind. Evidence given in support of this possible cosmic impact, at least for the northern hemisphere, are spikes in nanodiamonds ${ }^{10,11}$, platinum ${ }^{12}$, magnetic and glassy impact-related spherules, high-temperature minerals and melt glass, carbon spherules and/or osmium at the onset of the Younger Dryas ${ }^{9}$.

A spike in nanodiamonds has been reported for Younger Dryas deposits in Mexico. ${ }^{13}$ As yet, no corresponding site has been reported for the southern hemisphere. In the context of dates given here for palaeotemperature indices for the Wonderkrater sequence, it is recommended that exploratory analyses be undertaken on specific samples (notably 5605, 5606 and 5609 from Borehole 3) from this important South African site, to test whether or not there is evidence for nanodiamonds or other indicators of a cosmic impact that may have affected climates globally sometime after 12900 cal years BP.

\section{Acknowledgements}

This work was supported by the National Research Foundation (South Africa) and the DST/NRF Centre of Excellence for the Palaeosciences. I thank Louis Scott for his comments.

\section{References}

1. McCarthy TS, Ellery WN, Backwell L, Marren P, De Klerk B, Tooth S, et al. The character, origin and palaeoenvironmental significance of the Wonderkrater spring mound, South Africa. J Afr Earth Sci. 2010;58(1):115-126. http:// dx.doi.org/10.1016/j.jafrearsci.2010.02.004

2. Scott L. A Late Quaternary pollen record from the Transvaal bushveld, South Africa. Quat Res. 1982;17:339-370. https://doi.org/10.1016/00335894(82)90028-X

3. Scott L, Neumann FH, Brook GA, Bousman CB, Norström E, Metwally A. Terrestrial fossil-pollen evidence of climate change during the last 26 thousand years in southern Africa. Quat Sci Rev. 2012;32:100-118. https:// doi.org/10.1016/j.quascirev.2011.11.010

4. Scott $L$. Fluctuations of vegetation and climate over the last 75000 years in the Savanna Biome, South Africa: Tswaing Crater and Wonderkrater pollen sequences reviewed. Quat Sci Rev. 2016;145:117-133. https://doi. org/10.1016/j.quascirev.2016.05.035

5. Scott L, Thackeray JF. Multivariate analysis of late Pleistocene and Holocene pollen spectra from Wonderkrater, Transvaal, South Africa. S Afr J Sci. 1987;83:93-98.

6. Thackeray JF. Calibration of temperature indices from a Late Quaternary terrestrial sequence at Wonderkrater, South Africa. Quat Int. 1999;57/58:225227. https://doi.org/10.1016/S1040-6182(98)00063-9

7. Scott L, Holmgren K, Talma AS, Woodborne S, Vogel JC. Age interpretation of the Wonderkrater spring sediments and vegetation change in the Savanna Biome, Limpopo Province, South Africa. S Afr J Sci. 2003;99:484-488.

8. Thackeray JF, Scott L. The Younger Dryas in the Wonderkrater sequence, South Africa? Ann Transv Mus. 2006;43:111-112.

9. Kennett JP, Kennett DJ, Culleton BJ, Tortosa JEA, Bunch TE, Erlandson JM, et al. Reply to Holliday and Boslough et al: Synchroneity of widespread Bayesian-modeled ages support Younger Dryas impact hypothesis. Proc Natl Acad Sci USA. 2015;112(49):E6723-E6724. https://doi.org/10.1073/ pnas. 1520411112

10. Kennett DJ, Kennett JP, West A, Mercer C, Que Hee SS, Bement L, et al. Nanodiamonds in the Younger Dryas boundary sediment layer. Science. 2009;323(5910):94. https://doi.org/10.1126/science.1162819

11. Kurbatov AV, Mayewski P, Steffensen J, West A, Kennett D, Kennett J, et al. Discovery of a nanodiamond-rich layer in the Greenland ice sheet. J Glaciol. 2010;56(199):747-757. https://doi.org/10.3189/002214310794457191

12. Petaev MI, Huang S, Jacobsen SB, Zindler A. Large Pt anomaly in the Greenland ice core points to a cataclysm at the onset of Younger Dryas. Proc Natl Acad Sci USA. 2013;110(32):12917-12920. https://doi.org/10.1073/ pnas. 1303924110

13. Israde-Alcantara I, Bischoff JL, Domínguez-Vázquez G, Li H-C, DeCarli PS, Bunch TE, et al. Evidence from Central Mexico supporting the Younger Dryas extraterrestrial impact hypothesis. Proc Natl Acad Sci USA. 2012;109(13):E738-E747. https://doi.org/10.1073/pnas.1110614109 